\title{
Influence of environmental variables on diffusive greenhouse gas fluxes at hydroelectric reservoirs in Brazil
}

\author{
Rogério, JP. ${ }^{a},{ }^{*}$, Santos, $M A{ }^{a}{ }^{a}$ and Santos, EO. ${ }^{b}$ \\ ${ }^{a}$ Energy Planning Program, PPE/COPPE/UFRJ, Centro de Tecnologia, bloco C, sala 211 - CEP 21949-972, \\ Caixa Postal 68565, Cidade Universitária, Ilha do Fundão, Rio de Janeiro, RJ, Brazil \\ ${ }^{b}$ Department of Environmental Sciences, Forestry Institute, Federal Rural University of Rio de Janeiro, \\ Seropédica, RJ, Brazil \\ *e-mail: josiclea@hotmail.com / clea@ppe.ufrj.br \\ Received August 9, 2012 - Accepted November 29, 2012 - Distributed November 29, 2013
}

(With 6 figures)

\begin{abstract}
For almost two decades, studies have been under way in Brazil, showing how hydroelectric reservoirs produce biogenic gases, mainly methane $\left(\mathrm{CH}_{4}\right)$ and carbon dioxide $\left(\mathrm{CO}_{2}\right)$, through the organic decomposition of flooded biomass. This somewhat complex phenomenon is due to a set of variables with differing levels of interdependence that directly or indirectly affect greenhouse gas (GHG) emissions. The purpose of this paper is to determine, through a statistical data analysis, the relation between $\mathrm{CO}_{2}, \mathrm{CH}_{4}$ diffusive fluxes and environmental variables at the Furnas, Itumbiara and Serra da Mesa hydroelectric reservoirs, located in the Cerrado biome on Brazil's high central plateau. The choice of this region was prompted by its importance in the national context, covering an area of some two million square kilometers, encompassing two major river basins (Paraná and Tocantins-Araguaia), with the largest installed power generation capacity in Brazil, together accounting for around $23 \%$ of Brazilian territory. This study shows that $\mathrm{CH}_{4}$ presented a moderate negative correlation between $\mathrm{CO}_{2}$ and depth. Additionally, a moderate positive correlation was noted for $\mathrm{pH}$, water temperature and wind. The $\mathrm{CO}_{2}$ presented a moderate negative correlation for $\mathrm{pH}$, wind speed, water temperature and air temperature. Additionally, a moderate positive correlation was noted for $\mathrm{CO}_{2}$ and water temperature. The complexity of the emission phenomenon is unlikely to occur through a simultaneous understanding of all the factors, due to difficulties in accessing and analyzing all the variables that have real, direct effects on GHG production and emission.
\end{abstract}

Keywords: methane, carbon dioxide, environmental variables, reservoirs.

\section{Influência de parâmetros ambientais em fluxos difusivos de gases de efeito estufa em reservatórios hidrelétricos no Brasil}

\section{Resumo}

Há quase duas décadas, no Brasil, vêm sendo realizados estudos que revelam que os reservatórios hidrelétricos produzem gases biogênicos, principalmente o metano $\left(\mathrm{CH}_{4}\right)$ e o dióxido de carbono $\left(\mathrm{CO}_{2}\right)$, provenientes da decomposição orgânica da biomassa alagada. Observa-se que esse fenômeno é bastante complexo devido a uma gama de variáveis que possuem diferentes graus de interdependência e que influenciam diretamente ou indiretamente nas emissões de gases de efeito estufa (GEE). O objetivo deste trabalho é determinar o grau de relacionamento entre os fluxos difusivos de $\mathrm{CO}_{2}, \mathrm{CH}_{4}$ e variáveis ambientais dos Reservatórios Hidrelétricos de Furnas, Itumbiara e Serra da Mesa, através da análise estatística dos dados. Os reservatórios hidrelétricos estão situados no Bioma Cerrado, localizado no Planalto Central do Brasil. A escolha da região deu-se devido a sua importância no contexto nacional, já que corresponde a uma área de aproximadamente dois milhões de quilômetros quadrados, e, nela estão inseridas duas bacias (Bacia do Paraná e Bacia do Tocantins-Araguaia), com a maior capacidade instalada de energia elétrica do país. Esta duas bacias juntas abrangem $23 \%$ do território nacional. Neste estudo os resultados revelam que o $\mathrm{CH}_{4}$ apresentou correlação negativa, significativa e moderada com o $\mathrm{CO}_{2}$ e com a profundidade. Observou-se ainda correlação positiva e moderada com $\mathrm{pH}$, temperatura da água e velocidade do vento. $\mathrm{O} \mathrm{CO}_{2}$ apresentou correlação negativa, significativa e moderada com pH, com a velocidade do vento, temperatura da água e temperatura do ar. Observou-se também correlação positiva e moderada do $\mathrm{CO}_{2}$ com a temperatura da água. A complexidade do fenômeno de emissão dificilmente ocorrerá pelo entendimento simultâneo de todos os fatores, devido às dificuldades de acessar e analisar todas as variáveis que realmente têm implicação direta nesta produção/emissão de GEE.

Palavras-chave: metano, dióxido de carbono, variáveis ambientais, reservatórios. 


\section{Introduction}

Biogenic gases generated by the decomposition of biomass are a complex phenomenon, due to a range of variables with differing levels of interdependence, directly influencing greenhouse gas emissions from hydroelectric reservoirs.

Factors contributing to GHG emissions include the succession of microbiological communities during reservoir lifetimes (Dumestre et al., 2001), water column depth, water level variability, air temperature, water temperature, wind speed, dissolved oxygen concentration, water transparency, altitude and rainfall, among others (Kemenes, 2006; Lampert and Sommer, 2007; Tundisi, et al., 2007; Esteves, 2011; Ribeiro et al., 2011).

For almost two decades, studies have been under way of greenhouse gas emissions from hydroelectric reservoirs (Rudd et al., 1993; Rosa and Schaeffer, 1994a; Tremblay and Schetagne, 2006; Guerin et al., 2007; Weissenberger et al., 2010), presenting important observations on fluxes of $\mathrm{CO}_{2}, \mathrm{CH}_{4}$ and nitrous oxide (N2O) from hydroelectric reservoirs, including global estimates of emissions based on the flooded areas of different reservoirs (St. Louis et al, 2000).

The GHG emission rate per unit of electricity produced varies according to reservoir characteristics, including its size and the type of landscape flooded, as well as the power generation system used (Rudd et al., 1993). Especially in tropical regions, important knowledge has been built up that fosters a better understanding of the phenomenon of these gases released from Brazilian hydroelectric reservoirs, (Sikar et al., 2005), as well as GHG emission patterns (Rosa et al., 2004), comparisons of GHG fluxes from hydroelectric and thermoelectric power plants, and carbon circulation in reservoirs (Santos et al., 2006).

Extremely complex, the GHG emission phenomenon is unlikely to be understood through the simultaneous occurrence of all the factors involved, due to difficulties in accessing and analyzing all variables with direct effects on GHG production and emission.

In order to conduct this study, three hydroelectric power plants were selected in the Cerrado biome, located mainly on Brazil's high central plateau that covers some two million square kilometers, equivalent to $23 \%$ of Brazilian territory. Furthermore, these reservoirs are located within two the largest river basins in Brazil. The Paraná basin has the largest installed power generation capacity in Brazil, together with the heaviest demands while the Tocantins-Araguaia basin ranks second for power generation in Brazil.

The purpose of this paper is to determine through statistical data analyses the relation levels between environmental variables and carbon dioxide $\left(\mathrm{CO}_{2}\right)$ and methane $\left(\mathrm{CH}_{4}\right)$ fluxes at the following hydroelectric reservoirs: Furnas, Itumbiara and Serra da Mesa.

\section{Causal Mechanisms of Diffusive Fluxes in Hydroelectric Reservoirs}

\subsection{Wind effect}

The relation between high wind speeds and diffusive fluxes has been explored by several authors, with the pioneering studies conducted by Liss determining the relation between water-air gas transfers (Liss, 1973).

For carbon dioxide, Liss and Merlivat (1986) examined the empirical relations between water-air diffusive fluxes and wind speeds in oceans.

According MacInyre et al. (1995) gas fluxes at water-air interfaces depend mainly on two factors: concentration gradients between surface water and air, and physical transfers or turbulent energy at this interface.

The influence of wind speed variability on gas transfer velocities has been studied in aquatic bodies as ocean, lakes and riverine ecosystems (Wannikhof, 1992). Clark and colleagues suggested that wind is the primary source of surface turbulence at the water-air interface of the tidal Hudson River (Clark et al., 1995).

Some authors conclude that $\mathrm{CO}_{2}$ exchange coefficients in air-water interfaces are largely independent of wind at low wind speeds (Cole \& Caraco, 1998).

Ho et al. (2006) indicate that there is a quadratic relation between wind speed and gas transfer velocity in water-air interfaces over oceans.

Wind may have strong effects on thermal stratification and water column stability, strongly influencing the dynamics and vertical distribution of biogenic gases (Kemenes, 2006).

\subsection{Temperature effect}

In surface peat, Yavitt et al. (1987) found that temperature is the main variable controlling seasonal patterns in $\mathrm{CO}_{2}$ production.

Neue et al. (1997) showed that variations are controlled largely by soil solution temperatures and partial methane pressures. Supplementing these studies, the work of Moore \& Dalva (1993) revealed marked $(p<0.05)$ differences in carbon dioxide and methane emissions from peatland soils. Emissions of these gases were correlated with peat type, temperature and water table position. The proposed correlations of diffusive fluxes with temperatures showing $\mathrm{CO}_{2}$ and $\mathrm{CH}_{4}$ emissions at $23{ }^{\circ} \mathrm{C}$ were 2.4 and 6.6 times higher on average respectively, than those at $10^{\circ} \mathrm{C}$.

Lessard et al. (1994) found a positive correlation between soil surface $\mathrm{CO}_{2}$ fluxes and soil temperatures for forests $\left(R^{2}=0.74, s(\mathrm{y})=1.77 \mathrm{~g} \cdot \mathrm{m}^{-2} \cdot \mathrm{d}^{-1}\right)$ and croplands $\left(R^{2}=0.48, s(\mathrm{y})=1.10 \mathrm{~g} \cdot \mathrm{m}^{-2} \cdot \mathrm{d}^{-1}\right)$.

Another study demonstrated that methane fluxes were directly correlated with water levels and temperatures at all measurement locations, except two in the central part of the fen, where fluxes were lower (Rask et al., 2002). 
In northern peatlands, Macdonald et al. (1998) found positive linear correlations between $\mathrm{CH}_{4}$ emission rates and rising temperatures from pool and lawn monoliths.

\section{3. $p H$ effect}

When carbon dioxide dissolves in fresh water, it lowers the $\mathrm{pH}$, making it more acid. According Rice and Claypool (1981), the most important methane generation mechanism in marine sediments is the reduction of $\mathrm{CO}_{2}$ by hydrogen (electrons) produced through the anaerobic oxidation of organic matter.

Klinger et al. (1994) conclude that there are some indications that high $\mathrm{CH}_{4}$ fluxes cluster around $\mathrm{pH} 4$ and pH 7.

\subsection{Depth}

Previous studies have shown that $\mathrm{CH}_{4}$ concentrations in tropical reservoirs increase significantly at greater depths (Galy-Lacaux et al., 1999).

The depth of hydroelectric reservoirs strongly influences the vertical distribution of biogenic gases. Studies have demonstrated daily variations in these gas concentrations, which depend on gas mixtures in water columns (Kemenes, 2006; Esteves, 2011).

\subsection{Dissolved organic carbon}

Dissolved organic carbon (DOC) is produced by the decomposition of plants and animals and their excreta in water, with DOC decomposition caused by photochemical and microbial degradation (respiration), results in biogenic gases production (Lampert and Sommer, 2007; Esteves, 2011).

Dissolved organic carbon can decompose partially in the presence of dissolved oxygen, forming other organic or inorganic substances, such as $\mathrm{CO}_{2}$ for example. In the absence of oxygen, organic carbon may generate methane through methanogenesis (Esteves, 2011). Lu et al. (1999) observed that the higher levels of organic carbon in sediment resulted in higher methane effluxes from water bodies.

\section{Methodology}

\subsection{Characteristics of the reservoirs studied}

Located along the mid-course of the Grande River in Minas Gerais State, the Furnas hydroelectric power complex has eight power generation plants, six of which are in operation. The Itumbiara hydroelectric power complex is located on the Rio Paranaíba river (Paraná Hydrographic Region), on the boundary between Goiás and Minas Gerais States. The Serra da Mesa hydroelectric power complex is the largest in Brazil by water volume, playing a major role in the nation's energy sector; located in the Alto Tocantins river basin (Tocantins-Araguaia Hydrographic Region) in Goiás State, it has three power generation plants. Furnas reservoir is located at Grande river (Paraná Hydrographic Region) at Minas Gerais state (Figure 1).

The technical characteristics of the three reservoirs studied are presented in Table 1.

\subsection{Sampling methods}

$\mathrm{CO}_{2}$ and $\mathrm{CH}_{4}$ emanation were quantified using diffusion chambers of 1 liter volume and $0.05 \mathrm{~m}^{2}$ covered area. There are inverted containers that hold a trapped air volume over the water surface. Gases dissolved in water emanate into this volume.

Sampling the chamber at $0,2,4$ and 8 minutes, the volume enrichment rate was determined according to (Santos et al., 2011) by gas chromatography (Construmaq Gas Chromatograph with flame ionization detector for $\mathrm{CH}_{4}$ analyses and thermal conductivity detector for $\mathrm{CO}_{2}$, HayeSep D porous polymers packed columns), from which the emanation rate was calculated, dimensions were taken into account. The chambers were fitted with shields that prevent them from trapping bubbles as they rise.

The results of the gas chromatography analyses of samples taken from the floating chamber were matched to the four concentrations in order to measure the gas concentration increase (positive flux) or decrease (negative flux) in the chamber.

The following criteria were used to accept or reject the samples (UNESCO/IHA Greenhouse Gas, 2009):

1. Fluxes were accepted when the determination coefficient $\left(\mathrm{R}^{2}\right)$ of the adjustment function was greater than 0.85 and $\mathrm{p}<0.002$;

2. Fluxes were rejected when due to sample contamination by $\mathrm{CH}_{4}$ rich bubbles rising from the bottoming. If this does occur in the last measurement, that point was discarded and the only the first three points were used.

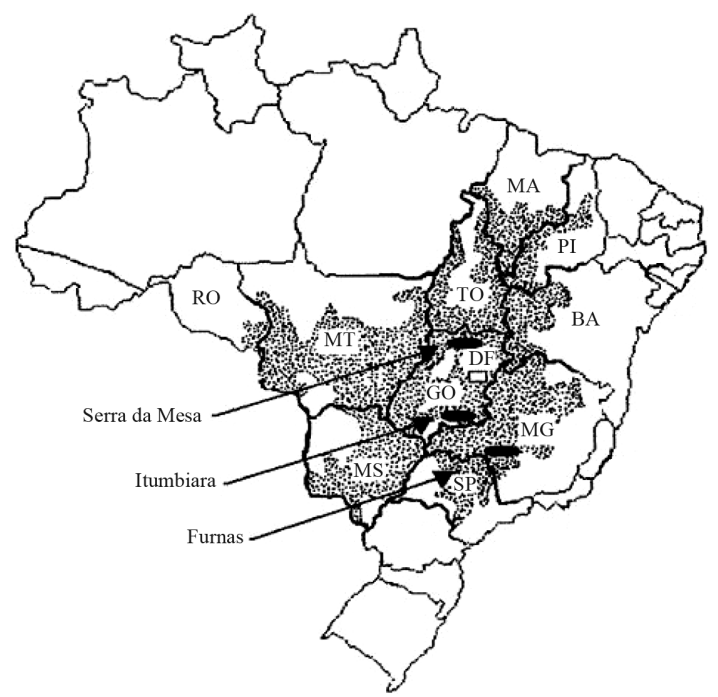

Figure 1 - Location of the hydroelectric reservoirs studied. 
Rogério, JP., Santos, MA. and Santos, EO.

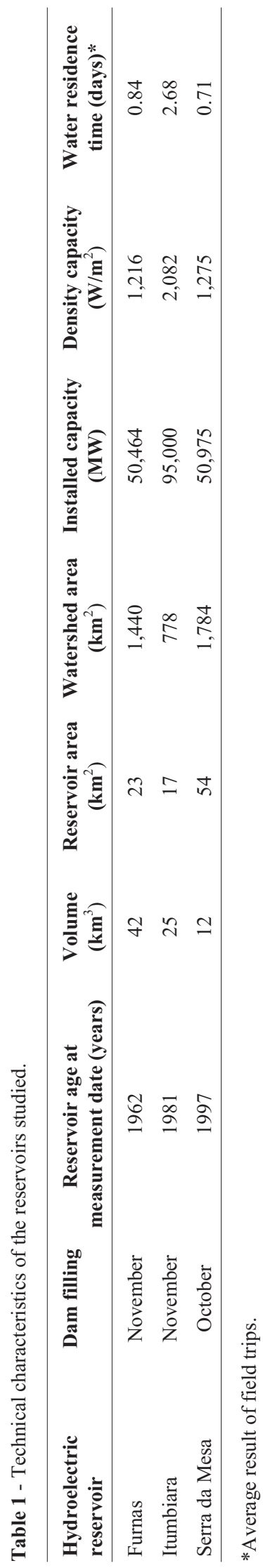

Should contamination occur before the last sample, the measurement at this point was discarded;

3 . If a problem detected during the chromatograph analysis resulted in the loss of the sample, it was discarded and the flux was calculated with the remaining three samples. After the samples passed through the filters and were accepted, the flux was calculated by the following equation:

$$
\text { Flux }=\frac{\text { Rate } \times \mathrm{P} \times \mathrm{F} 1 \times \mathrm{F} 2 \times \mathrm{V}}{\mathrm{SP} \times \mathrm{R} \times \mathrm{T} \times \mathrm{A}}
$$

where Rate: growth rate of gas concentration over time $\left(\mathrm{ppm} . \mathrm{s}^{-1}\right)$, given by the gradient; P: atmospheric pressure in the laboratory at the time of analysis (atm.); F1: molecular weight of the gas (44 for $\mathrm{CO}_{2}, 16$ for $\mathrm{CH}_{4}$ ); F2: conversion factor from seconds to days $(86,400 \mathrm{~s})$; $\mathrm{V}$ : air volume in the chamber $\left(\mathrm{m}^{3}\right)$; SP: standard pressure at mean sea level $(101.33 \mathrm{kPa})$; R: universal gas constant $\left(0.08207 \mathrm{~L}\right.$ atm. $\left.\mathrm{mol}^{-1} \cdot \mathrm{K}^{-1}\right) \mathrm{A}$ : chamber area in contact with water $\left(\mathrm{m}^{2}\right)$; T: air temperature at time of laboratory analysis $(\mathrm{K})$; the findings are presented in $\mathrm{mg}$ (gas) $\mathrm{m}^{-2} \mathrm{~d}^{-1}$.

\subsection{Location of sampling sites}

The geographical location of the sampling sites in the studied reservoirs is shown in Figures 2 to 4 . The sampling sites were distributed among the reservoirs taking into account two distinct parts of these water bodies: their main channels and their branches, whose hydrodynamic processes more closely resemble stagnant water (Table 2).

The diffusive gas fluxes were measured at three hydroelectric reservoirs owned by Furnas Centrais Elétricas S.A. Each reservoir was sampled at least three times a year, covering the dry, wet and transition seasons (wetdry) as shown in Table 3.

\subsection{Statistical analysis}

For statistical treatment, the mean results of the diffusive $\mathrm{CH}_{4}$ and $\mathrm{CO}_{2}$ fluxes were used, at the hydroelectric reservoirs. These data were obtained through collecting samples.

In order to calculate the correlation coefficients in addition to physical and chemical variables such as: wind speed, air temperature, water temperature, $\mathrm{pH}$ and DOC. All these variables are possibly related to the production and emission of GHGs (Figure 5).

The normality of all the variables was checked through the Kolmogorov-Smirnov D test (Wilks, 2006), with estimated dataset parameters, in order to determine whether the set is well modeled for normal distribution, thus selecting the best method for describing the data and the best way of conducting this study.

The Pearson correlation matrix was used to analyze the relations between the environmental variables and the $\mathrm{CH}_{4}$ and $\mathrm{CO}_{2}$ fluxes. This method was selected as it is useful for simultaneous analyses of correlations among 


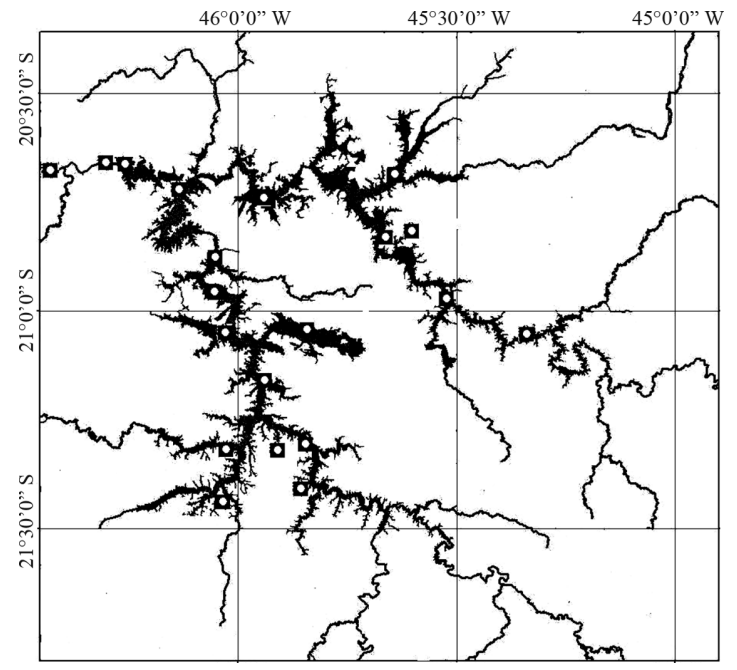

Figure 2 - Sampling sites at Furnas hydropower reservoir.

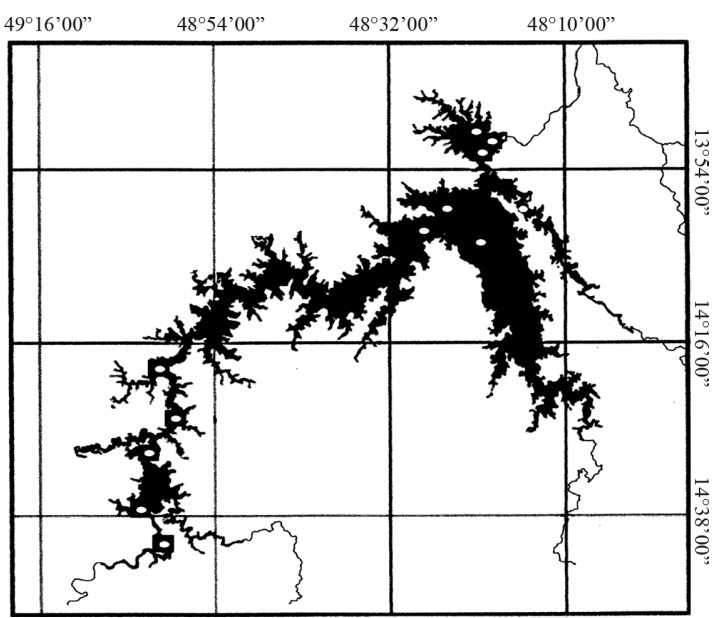

Figure 3 - Sampling sites at Serra Mesa hydropower reservoir.

many variables. In order to conduct this study, pair deletion was used, with a significance level of $5 \%(\mathrm{p}<0.05)$.

The Kruskal-Wallis test is a nonparametric test (Helsel, 1987) used here to compare the three reservoirs studied and provide comparisons between GHGs fluxes of three sampling campaigns in each reservoir and the environmental variables. It can be used to analyse several different samples and it tests the null hypothesis.

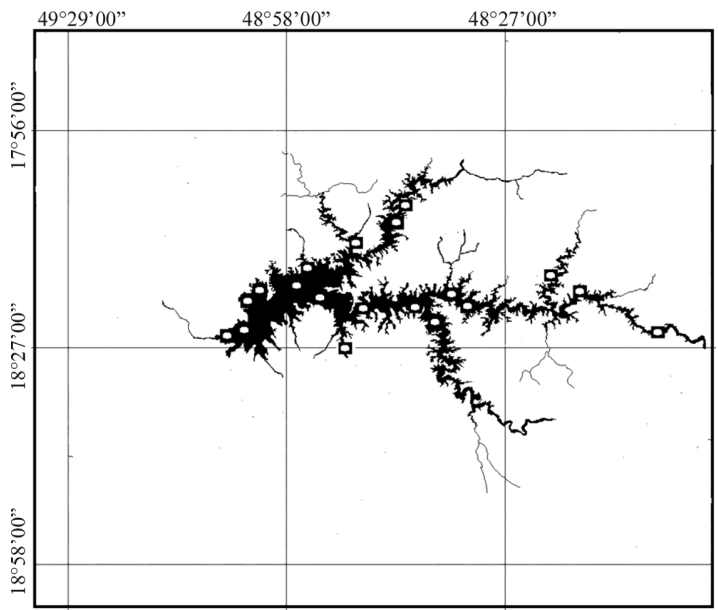

Figure 4 - Sampling sites at Itumbiara hydropower reservoir.

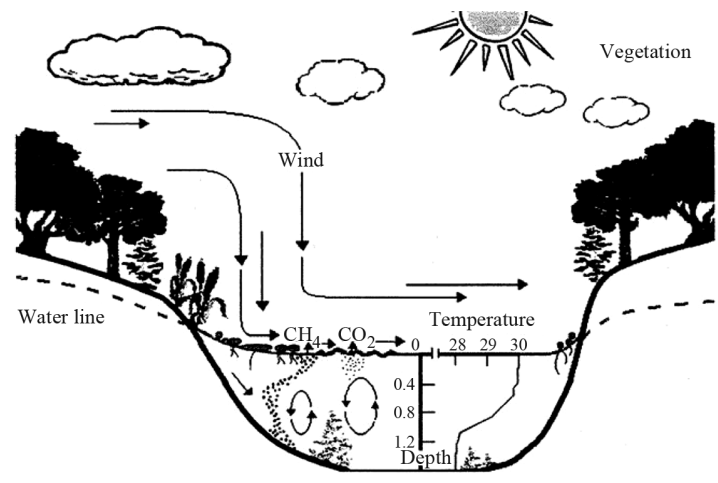

Figure 5 - Schematic diagram of greenhouse gas production and emission, and relationships with some environmental variables.

The Mann-Whitney test (Wilks, 2006) is used to analyze data from a two different groups of results. The null hypothesis assumes that the two distributions do not differ systematically from each other. The alternative hypothesis, on the other hand, states that the two distributions differ systematically.

\section{Results and Discussions}

\subsection{Descriptive statistics of diffusive fluxes and environmental variables}

The Boxplot presents the frequency distribution of the diffusive $\mathrm{CH}_{4}$ and $\mathrm{CO}_{2}$ fluxes by field trip at each res-

Table 2 - Spatial localization of sampling sites in the reservoir area.

\begin{tabular}{lcc}
\hline Hydropower reservoir & Main channel of reservoir (\%) & Regions with poor water circulation (reservoir arms) (\%) \\
\hline Furnas & 61 & 39 \\
Itumbiara & 58 & 42 \\
Serra da Mesa & 64 & 36 \\
\hline
\end{tabular}


ervoir (Figure 6). The frequency distribution all reservoirs has similar results for the $\mathrm{CH}_{4}$ fluxes.

The result of the Kruskal-Wallis test, at the 0.05 level, shows that the populations are not significantly different (Table 4). Results obtained for $\mathrm{CH}_{4}$ and $\mathrm{CO}_{2}$ fluxes, suggest that the observed differences between the three periods studied are significant (Table 5).

The Furnas reservoir presents a mean $\mathrm{CH}_{4}$ flux for the transition period (wet-dry) that is higher than in the dry season $(U=468 ; Z=2.381$; Exact. Prob > $|\mathrm{U}|=0.016$; Asymp. Prob $>|\mathrm{U}|=0.017)$ thus differing from the pattern found at the other reservoirs (Figure 6a). At the 0.05 level, the two distributions are significantly different.

The Mann-Whitney test shows whether the distributions between two groups are the same, with the alternative hypothesis that the populations are significantly different, or one larger than the other.

This difference might possibly be explained through the reduction recorded in wind speed $\left(0.70 \mathrm{~m} . \mathrm{s}^{-1}\right)$ during the sampling period (Table 6), as thermal stratification might

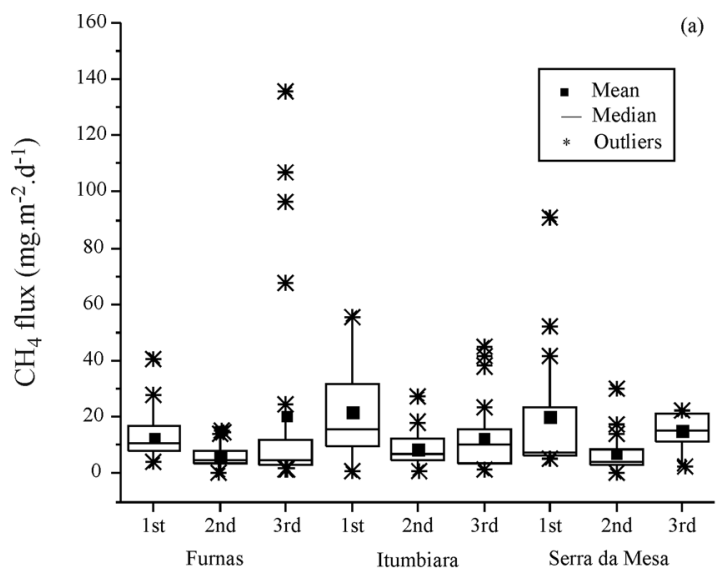

Table 4 - Kruskal-Wallis test statistics of the studied reservoirs.

\begin{tabular}{lccc}
\hline & Chi-Square & DF & Prob $>$ Chi-Square \\
\hline $\mathbf{C H}_{4}$ & 5.430 & 2 & 0.066 \\
$\mathbf{C O}_{2}$ & 4.046 & 2 & 0.132 \\
\hline
\end{tabular}

At the 0.05 level, the populations are not significantly different.

Table 5 - Statistical test to compare different periods.

\begin{tabular}{lcccc}
\hline & & Chi-Square & DF & $\begin{array}{c}\text { Prob }>\text { Chi- } \\
\text { Square }\end{array}$ \\
\hline Furnas & $\mathrm{CH}_{4}$ & 11.114 & 2 & 0.003 \\
& $\mathrm{CO}_{2}$ & 20.801 & 2 & $3.040 \mathrm{E}-5$ \\
\multirow{3}{*}{ Itumbiara } & $\mathrm{CH}_{4}$ & 10.734 & 2 & 0.004 \\
& $\mathrm{CO}_{2}$ & 8.229 & 2 & 0.016 \\
Serra da Mesa & $\mathrm{CH}_{4}$ & 12.238 & 2 & 0.002 \\
& $\mathrm{CO}_{2}$ & 6.762 & 2 & 0.033 \\
\hline
\end{tabular}

At the 0.05 level, the populations are significantly different.

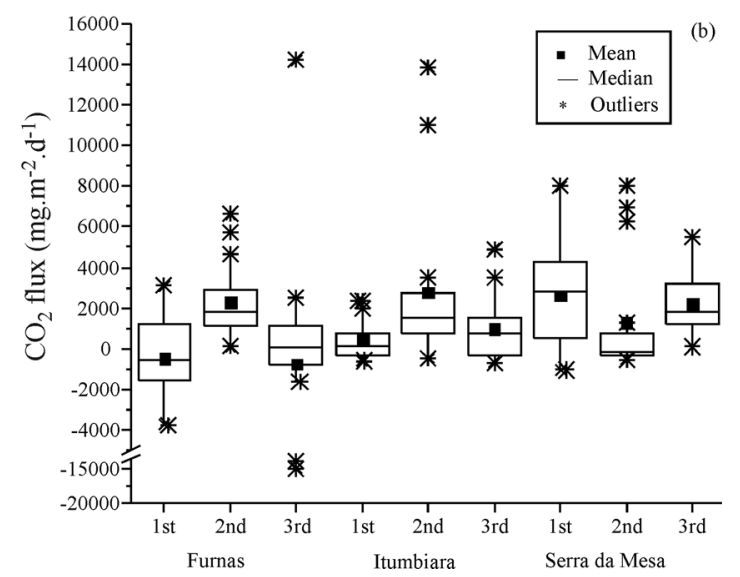

Figure 6 - Frequency distribution of the diffusive fluxes by field trips for the Furnas, Itumbiara and Serra da Mesa reservoirs (a) $\mathrm{CH}_{4}$ flux and (b) $\mathrm{CO}_{2}$ flux.

Table 3 - Sampling period at the studied reservoirs.

\begin{tabular}{lcccc}
\hline Hydroelectric reservoir & Field trip & Date & Season & Total sample \\
\hline \multirow{2}{*}{ Furnas } & 1st. & $11 / 2005$ & Dry & $78\left(\mathrm{CH}_{4}\right)$ \\
& 2nd. & $04 / 2006$ & Wet & $66\left(\mathrm{CO}_{2}\right)$ \\
& 3rd. & $07-08 / 2006$ & Transition (Wet-Dry) & $78\left(\mathrm{CH}_{4}\right)$ \\
Itumbiara & 1 st. & $11 / 2004$ & Dry & $57\left(\mathrm{CO}_{2}\right)$ \\
& 2nd. & $03 / 2005$ & Wet & $47\left(\mathrm{CH}_{4}\right)$ \\
Serra da Mesa & 3rd. & $08 / 2005$ & Transition (Wet-Dry) & $47\left(\mathrm{CO}_{2}\right)$ \\
\hline
\end{tabular}


have increased due to this reduction, resulting in a higher accumulation of $\mathrm{CH}_{4}$ (Lampert and Sommer, 2007).

An examination of the gap between the mean $\left(20.28 \mathrm{mg} \cdot \mathrm{m}^{-2} \cdot\right.$ day $\left.^{-1}\right)$ and median $\left(4.50 \mathrm{mg} \cdot \mathrm{m}^{-2} \cdot\right.$ day $\left.^{-1}\right)$ shows the level of deviation in the measurements dispersion, which can be explained by the spatial variability of the samples (Table 2).

Comparing the $\mathrm{CO}_{2}$ flux frequency distribution for the three reservoirs, the Serra da Mesa reservoir posts different results. During the dry season (first field trip), the average $\mathrm{CO}_{2}$ flux $\left(2,617.88 \mathrm{mg} \cdot \mathrm{m}^{-2}\right.$.day $\left.{ }^{-1}\right)$ was similar to the rainy season values (Figure $6 \mathrm{~b}$ ), which may reflect more active aerobic bacteria due to higher oxygen availability in the water column.

Sampling in Serra da Mesa reservoir initially occurred when the reservoir had been filling for six years, with widespread decomposition of terrestrial vegetation was flooded, and huge decomposition rates, mainly anaerobic, was very intense.

During the rainy season (second field trip) the average flux $\left(\mathrm{CH}_{4}=7.12\right.$ and $\mathrm{CO}_{2}=1,281.68 \mathrm{mg} \cdot \mathrm{m}^{-2}$.day $\left.{ }^{-1}\right)$ was less than expected for this period, compared to the other reservoirs. The average for this period presented characteristic values usually found for dry season (Table 6).

The Serra da Mesa Reservoir presented a higher average concentration of DOC (10.62 mg. $\left.\mathrm{L}^{-1}\right)$ during the dry season (Table 6), which may be due to seasonal variations of autochthonous biomass production related to the nutrients inputs. The dissolved organic carbon load values are influenced by precipitation and water flows in these environments.

During the dry season, the reservoir level was five to ten meters below average, with the banks showing discoloration typical of soil appearing after flooding. It was possible to observe that during the sampling period there was heavy rainfall $(157.2 \mathrm{~mm})$ and an increase in the inflow $\left(304 \mathrm{~m}^{3} / \mathrm{s}\right)$, which may give rise to a greater addition of organic matter and an increase in one of its main fractions, dissolved organic carbon. Studies on the DOC concentration in lakes show that it is considered indicative of partial carbon dioxide pressure $\left(\mathrm{pCO}_{2}\right)$ and consequently $\mathrm{CO}_{2}$ flux to the atmosphere. Lennon (2004) demonstrated experimentally in mesocosms the increase of $\mathrm{CO}_{2}$ flow with additions of dissolved organic carbon. Other authors such as Prairie et al. (2002) and Jonsson et al. (2003) also demonstrated a linear relationship between DOC and $\mathrm{CO}_{2}$ flux in boreal and temperate lakes, respectively.

\subsection{Correlation analysis of diffusive fluxes and environmental variables}

The correlation coefficients ( $\tilde{\mathrm{n}})$ between the average diffusive fluxes of $\mathrm{CH}_{4}$ and $\mathrm{CO}_{2}$, the DOC and the environmental variables at the reservoirs studied are shown in Tables 7 to 9 .
The analysis shows a moderately positive correlation between wind speed and $\mathrm{CH}_{4}$ fluxes at the Itumbiara Reservoir $(r=0.322)$ and Serra da Mesa $(r=0.692)$. The wind speed may have marked effects on thermal stratification and water column stability, strongly influencing the dynamics and vertical distribution of biogenic gases, which might possibly explain the correlation between these two variables. Similar effects were observed by Kemenes (2006) in Balbina Reservoir, showing that wind may exert a strong influence on gas distribution in the water column.

At the Furnas Reservoir, the $\mathrm{CH}_{4}$ flux showed a moderate negative correlation $(\mathrm{r}=-0.338)$ with $\mathrm{CO}_{2}$, possibly explained by $\mathrm{CH}_{4}$ oxidation resulting from the formation of $\mathrm{CO}_{2}$ in the presence of oxygen or an increase in its concentration (Utsumi apud Esteves, 2011). Additionally, a moderate positive correlation $(\mathrm{r}=0.508)$ was noted between the $\mathrm{CH}_{4}$ flux and the $\mathrm{pH}$.

A low positive correlation $(\mathrm{r}=0.263)$ between the $\mathrm{CH}_{4}$ flux and the DOC may be explained by $\mathrm{CH}_{4}$ production at the sediment-water interface, with organic carbon used in the methanogenic process.

The $\mathrm{CH}_{4}$ flux was correlated with depth at the Itumbiara Reservoir $(r=-0.377)$. Earlier studies have shown that dissolved $\mathrm{CH}_{4}$ concentrations increased significantly at lower depths in tropical reservoirs (Galy-Lacaux et al., 1999). The possible reason for the increased flux may be related to the observed growth of gramineous plants at the bottom of the reservoir, acting as a new source of decaying organic matter.

Moderate positive correlation between $\mathrm{CH}_{4}$ flux and water temperature was noted at the Serra da Mesa reservoir $(r=0.397)$. The water temperature directly influences the solubility of gases and therefore the phenomenon of exchange of gases in the air-water interface.

The correlation analysis showed that two of the reservoirs studied presented moderate negative correlation between $\mathrm{CO}_{2}$ and $\mathrm{pH}$, suggesting that biological processes such as primary production and mineralization have a significant effect on these variations (Chagas \& Suzuki, 2004). At the Furnas Reservoir, the correlation coefficient value was equal to -0.559 , reaching -0.521 at Itumbiara. In water, $\mathrm{CO}_{2}$ tends to form carbonic acid $\left(\mathrm{H}_{2} \mathrm{CO}_{3}\right)$, which could explain the moderate negative correlation with $\mathrm{pH}$. Earlier studies show that carbonic acid and free carbon dioxide predominates at $\mathrm{pH}$ levels less than 6.4 (Lampert and Sommer, 2007; Esteves, 2011).

Negative low correlation $(\mathrm{r}=-0.305)$ between $\mathrm{CO}_{2}$ and DOC was noted for the Furnas reservoir, which can be explained by the different metabolic processes that follow the water column profile in this ecosystem. They include the DOC photodegradation process, which consists of the absorption of sunlight and its subsequent oxidation, resulting in $\mathrm{CO}_{2}$, which is a form of dissolved organic carbon.

The correlation analysis showed a significant correlation between $\mathrm{CO}_{2}$ and water temperature at the two res- 


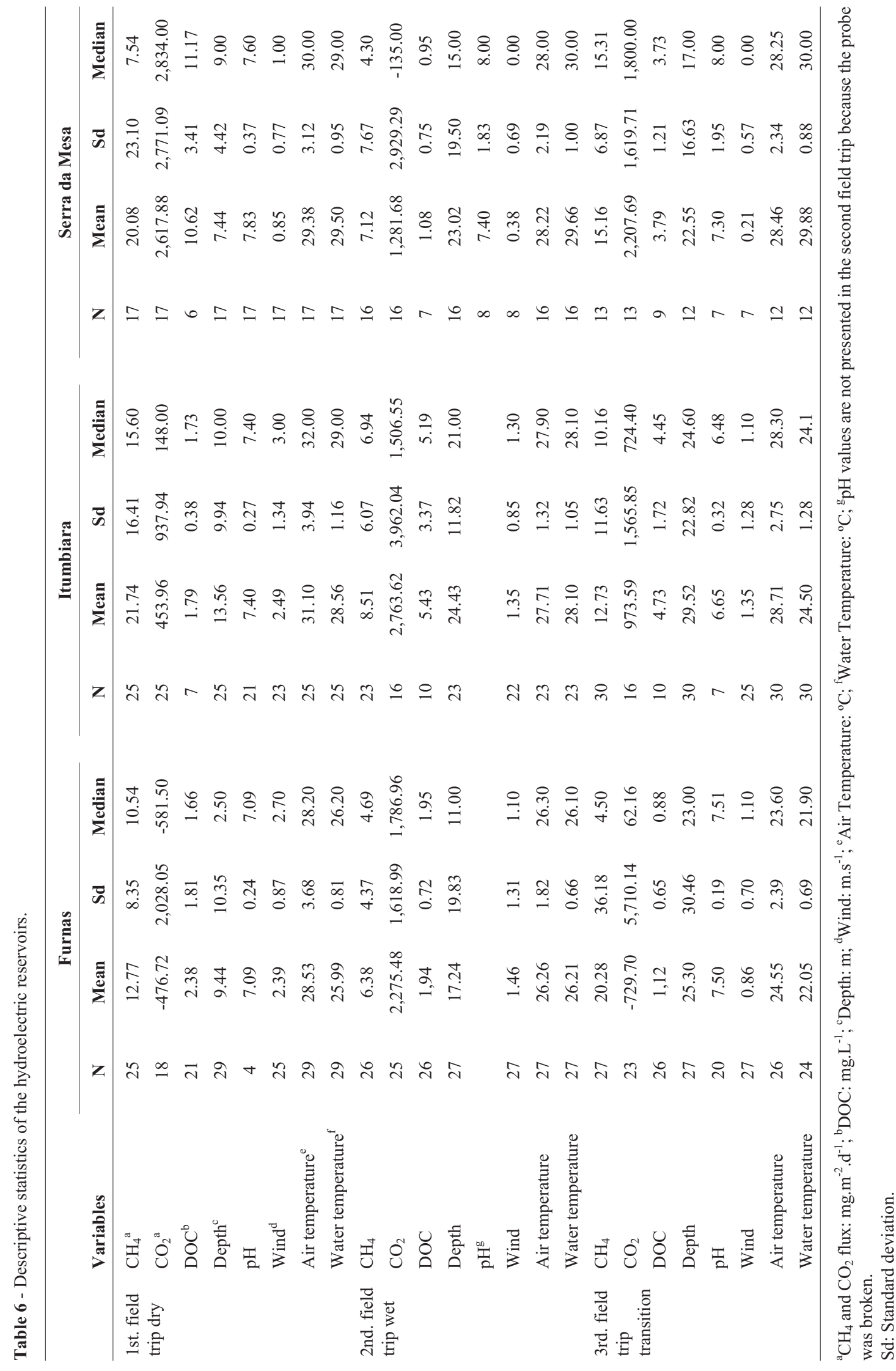


Table 7 - Correlation coefficients for the Furnas reservoir (CH4: methane flux; CO2: carbon dioxide flux; DOC: dissolved organic carbon carbon; Depth: lake depth; pH: potential of hydrogen; Wind: wind speed; Air Temp.: air temperature; Water Temp.: water temperature).

\begin{tabular}{|c|c|c|c|c|c|c|c|c|}
\hline & $\mathrm{CH}_{4}$ & $\mathrm{CO}_{2}$ & DOC & Depth & pH & Wind & Air temp. & $\begin{array}{l}\text { Water } \\
\text { temp. }\end{array}$ \\
\hline $\mathrm{CH}_{4}$ & 1 & & & & & & & \\
\hline $\mathrm{CO}_{2}$ & $-0.338^{*}$ & 1 & & & & & & \\
\hline DOC & $0.263 *$ & $-0.305^{*}$ & 1 & & & & & \\
\hline Depth & 0.072 & -0.016 & -0.071 & 1 & & & & \\
\hline $\mathrm{pH}$ & $0.508^{*}$ & $-0.559 *$ & $0.559^{*}$ & -0.047 & 1 & & & \\
\hline Wind & 0.017 & 0.115 & -0.081 & 0.008 & -0.232 & 1 & & \\
\hline Air temperature & 0.177 & -0.011 & -0.050 & -0.140 & 0.276 & $0.228^{*}$ & 1 & \\
\hline Water temperature & -0.180 & $0.338^{*}$ & -0.206 & $-0.326^{*}$ & $-0.642 *$ & $0.349^{*}$ & $0.554^{*}$ & 1 \\
\hline
\end{tabular}

*Marked correlations are significant for $\mathrm{p}<0.05$.

Table 8 - Correlation coefficients for the Itumbiara reservoir (CH4: methane flux; $\mathrm{CO} 2$ : carbon dioxide flux; DOC: dissolved organic carbon carbon; Depth: lake depth; pH: potential of hydrogen; Wind: wind speed; Air Temp.: air temperature; Water Temp.: water temperature).

\begin{tabular}{|c|c|c|c|c|c|c|c|c|}
\hline & $\mathrm{CH}_{4}$ & $\mathrm{CO}_{2}$ & DOC & Depth & $\mathrm{pH}$ & Wind & Air temp. & $\begin{array}{l}\text { Water } \\
\text { temp. }\end{array}$ \\
\hline $\mathrm{CH}_{4}$ & 1 & & & & & & & \\
\hline $\mathrm{CO}_{2}$ & -0.003 & 1 & & & & & & \\
\hline DOC & -0.301 & 0.199 & 1 & & & & & \\
\hline Depth & $-0.377^{*}$ & -0.128 & -0.016 & 1 & & & & \\
\hline $\mathrm{pH}$ & -0.026 & $-0.521 *$ & 0.260 & -0.293 & 1 & & & \\
\hline Wind & $0.322 *$ & $-0.366^{*}$ & -0.024 & -0.162 & 0.290 & 1 & & \\
\hline Air temperature & 0.070 & -0.088 & $-0.391 *$ & -0.136 & 0.305 & $-0.337^{*}$ & 1 & \\
\hline Water temperature & 0.041 & -0.182 & -0.271 & $-0.237^{*}$ & $0.819^{*}$ & 0.128 & $0.390^{*}$ & 1 \\
\hline
\end{tabular}

*Marked correlations are significant for $\mathrm{p}<0.05$.

Table 9 - Correlation coefficients for the Serra da Mesa reservoir (CH4: methane flux; $\mathrm{CO} 2$ : carbon dioxide flux; DOC: dissolved organic carbon carbon; Depth: lake depth; $\mathrm{pH}$ : potential of hydrogen; Wind: wind speed; Air Temp.: air temperature; Water Temp.: water temperature).

\begin{tabular}{|c|c|c|c|c|c|c|c|c|}
\hline & $\mathrm{CH}_{4}$ & $\mathrm{CO}_{2}$ & DOC & Depth & pH & Wind & Air temp. & $\begin{array}{l}\text { Water } \\
\text { temp. }\end{array}$ \\
\hline $\mathrm{CH}_{4}$ & 1 & & & & & & & \\
\hline $\mathrm{CO}_{2}$ & -0.117 & 1 & & & & & & \\
\hline DOC & 0.256 & 0.024 & 1 & & & & & \\
\hline Depth & -0.159 & -0.267 & -0.347 & 1 & & & & \\
\hline $\mathrm{pH}$ & -0.135 & -0.286 & 0.193 & 0.216 & 1 & & & \\
\hline Wind & $0.692 *$ & -0.181 & 0.369 & $-0.446^{*}$ & -0.312 & 1 & & \\
\hline Air temperature & 0.172 & $-0.441^{*}$ & $0.466^{*}$ & 0.251 & 0.249 & 0.181 & 1 & \\
\hline Water temperature & $0.397 *$ & $-0.571^{*}$ & -0.036 & 0.008 & -0.170 & $0.376^{*}$ & $0.418^{*}$ & 1 \\
\hline
\end{tabular}

*Marked correlations are significant for $\mathrm{p}<0.05$. 
ervoirs studied. Water temperature was correlated in a positive moderate manner (0.338) with $\mathrm{CO}_{2}$ at the Furnas reservoir, but was extremely negative $(-0.571)$ for the Serra da Mesa reservoir, possibly due to thermal stratification. At the Serra da Mesa reservoir, moderate negative correlation (-0.441) was noted between $\mathrm{CO}_{2}$ and air temperature. The analysis presented a significant correlation between water temperature and $\mathrm{CO}_{2}$ for the two reservoirs under study. Daily variations were observed in the temperatures between the surface and the bottom of the reservoir, isolating its layers and resulting in higher and/or lower $\mathrm{CO}_{2}$ concentrations. For the Furnas reservoir, there is a moderately positive correlation between the water temperature and $\mathrm{CO}_{2}(0.338)$. In this reservoir, a negative flux of $\mathrm{CO}_{2}$ was observed in the dry season $\left(-476.72 \mathrm{mg} \cdot \mathrm{m}^{-2} \cdot \mathrm{d}^{-1}\right)$ and in the transitional season $\left(-729.70 \mathrm{mg} \cdot \mathrm{m}^{-2} \cdot \mathrm{d}^{-1}\right)$, and low values in water temperature. According to Esteves (2011), the lower the temperature, the greater the solubility of gases in water, and the greater the rise in temperature, the greater the system's metabolism will be. For the Serra da Mesa reservoir, a negative correlation was found (-0.571) between water temperature and $\mathrm{CO}_{2}$, possibly due to thermal stratification. Also for Serra da Mesa, a moderately negative correlation (-0.441) was found between $\mathrm{CO}_{2}$ and air temperature, possibly influenced by oxygen concentration, a factor that is directly related to the temperature (Kemenes, 2006; Esteves, 2011).

Other variables presented significant correlations with $\mathrm{CO}_{2}$ fluxes in Itumbiara Reservoir. Wind speed showed a moderate negative correlation $(r=-0.366)$ with $\mathrm{CO}_{2}$, probably related to water mass circulation, which may have marked impacts on water column thermal structures, strongly influencing the vertical distribution of biogenic gases (Esteves, 2011), also causing water surface mixing with the underlying water (Lampert \& Sommer, 2007). Wind is among the most important factors for gas transfer rates at water-air interfaces.

Comparing $\mathrm{CO}_{2}$ flux frequency distributions at all three reservoirs, Serra da Mesa behaved differently from the others. During the dry season (first field trip), the average flux value increased $\left(2,617.88 \mathrm{mg} \cdot \mathrm{m}^{-2}\right.$.day $\left.{ }^{-1}\right)$, reaching a level similar to the rainy season values.

During the rainy season (second field trip), the average $\mathrm{CO}_{2}$ flux $(1,281.68 \mathrm{mg} \cdot \mathrm{m}-2$.day-1) was lower than expected for this period, compared to the other two reservoirs, with values more characteristic of the dry season.

\section{Conclusions}

The variability of the diffusive fluxes of $\mathrm{CH}_{4}$ was positively influenced by the environmental variables, wind and dissolved organic carbon; and negatively influenced by $\mathrm{CO}_{2}$, depth and water temperature.

The environmental variables that negatively influenced the variability of the diffusive fluxes of $\mathrm{CO}_{2}$ were dissolved organic carbon, air temperature and wind. The water temperature influenced the $\mathrm{CO}_{2}$ fluxes both positively and negatively.

Establishing the relationship between the diffusive fluxes of $\mathrm{CH}_{4}$ and $\mathrm{CO}_{2}$ and the environmental variables represents a contribution to greater understanding of the processes involved. Its importance is due above all to the fact that the study was carried out in a region of the cerrado biome, as most of the research done emphasizes the reservoirs in the Amazon region as great sources of greenhouse gas emissions.

\section{Acknowledgments}

This study was financed by Furnas Centrais Elétricas S.A. through the Carbon Budgets in Hydroelectric Reservoirs research project.

We thank the Graduate Coordination Agency of the Ministry of Education (CAPES) for granting a doctoral study to the first author of this paper and the National Council for Scientific and Technological Development $(\mathrm{CNPq})$ for the research productivity grant awarded to the second author of this paper. We thank the National Science and Technology Institute (INCT) - Climate Change - Emissions from Lakes and Reservoirs Sub-Project.

\section{References}

CLARK, JF., SCHLOSSER, P., SIMPSON, HJ., STUTE, M., WANNINKHOF, R. and HO, DT., 1995. Relationship between gas transfer velocities and wind speeds in the tidal Hudson River determined by the dual tracer technique. In: Air-Water Gas Transfer, Proceedings of the third international symposium on air-water gas transfer, B. Jaehne and E.C. Monahan, editors, AEON Verlag \& Studio, Hanau, Germany, p. 785-800.

CHAGAS, GG. and SUZUKI, MS., 2004. Seasonal Hydrochemical Variation in a Tropical Coastal Lagoon (Açu Lagoon, Brazil). Braz. J. Biol., vol. 65, no. 4, p. 597-607.

COLE, JJ. and CARACO, NF., 1998. Atmospheric exchange of carbon dioxide in a low-wind oligotrophic lake measured by the addition of $\mathrm{SF}_{6}$. Limnol. Oceanogr., vol. 43, no. 4, p. 647-656.

DUMESTRE, JF., CASAMAYOR, EO., MASSANA, R. and PEDRÓS-ALIÓ, C., 2001. Changes in bacterial and archaeal assemblages in an equatorial river induced by the water eutrophication of Petit Saut dam reservoir (French Guiana). Aquat. Microb. Ecol., vol. 26, p. 209-221.

ESTEVES, FA., 2011. Fundamentos de Limnologia. Editora Interciência: Rio de Janeiro, 826p.

FENCHEL, T., KING, GM. and BLACKBURN, TH., 1998. Bacterial Biogeochemistry. 2nd ed. Academic Press: California and London, 307p.

GALY-LACAUX, C., DELMAS, R., KOUADIO, G., RICHARD, S. and GOSSE, P., 1999. Long-term Greenhouse gas emissions from hydroeletric reservoirs in tropical forest regions. Global Biogeochem. Cycles, vol. 13, p. 503-517.

GUÉRIN, F., ABRIL, G., SERÇA, D., DELON, C., RICHARD, S., DELMAS, R., TREMBLAY, A. and VARFALVY, L., 2007. Gas Transfer Velocities of $\mathrm{CO}_{2}$ and $\mathrm{CH}_{4}$ in a Tropi- 
cal Reservoir and its River Downstream. J. Mar. Syst, vol. 66, p. 161-172.

HELSEL, DR., 1987. Advantages of Nonparametric Procedures for Analysis of Water Quality Data. Hydrol. Sci. J., vol. 32, p. 179-190.

HO, DT., LAW, CS., SMITH, MJ., SCHLOSSER, P., HARVEY, M. and HILL, P., 2006. Measurements of air-sea gas exchange at high wind speeds in the Southern Ocean: Implications for global parameterizations. Geophys. Res. Lett., vol. 33, p. L16611.

JONSSON, A., KARLSSON, J. and JANSSON, M., 2003. Sources of carbon dioxide Supersaturation in Clearwater and Humic Lakes in Northern Sweden. Ecosystems, vol. 6, p. 224-235.

KEMENES, A., 2006. Estimativa das Emissões de Gases de Efeito Estufa $\left(\mathrm{CO}_{2}\right.$ e $\left.\mathrm{CH}_{4}\right)$ pela Hidrelétrica de Balbina, Amazônia Central, Brasil. Manaus: Universidade Federal do Amazonas, 95p. Tese de Doutorado em Biologia Tropical e Recursos Naturais.

KLINGER, LF., ZIMMERMAN, PR., GREENBERG, JP., HEIDT LE. and GUENTHER, AB., 1994. Carbon trace gas fluxes along a successional gradient in the Hudson Bay lowland. J. Geophys. Res., vol. 99, no. D1, p. 14691494.

LAMPERT, W. and SOMMER, U., 2007. Limnoecology: The Ecology of Lakes and Streams. 2nd ed. Oxford: University Press, New York, 324p.

LENNON, JT., 2004. Experimental Evidence that Terrestrial Carbon Subsidies Increase $\mathrm{CO}_{2}$ flux from Lake Ecosystems. Oecologia vol. 138, p. 584-591.

LESSARD, R., ROCHETTE, P., TOPP, E., PATTEY, E., DESJARDINS, RL. and BEAUMONT, G., 1994. Methane and carbon dioxide fluxes from poorly drained adjacent cultivated and forest sites. Can. J. Soil Sci., vol. 74, no. 2, p. 139-146.

LISS, PS., 1973. Processes of gas exchange across an air-water interface. Deep Sea Res. Ocean. Abstracts, vol. 20, no. 3, p. 221-238.

LISS, PS. and MERLIVAT, L., 1986. Air-sea gas exchange rates: Introduction and synthesis. In: The Role of Air-Sea Exchange. Geochemical Cycling. P. Buat-Menard (ed), D. Reidel, Hingham, Mass., p. 113-129.

LU, Y., WASSMANN, R., NEUE H. and HUANG, C., 1999 Dynamics of Dissolved Organic Carbon and Methane Emissions in a Flooded Rice Soil. Soil Sci. Soc. Am. J., vol. 64 , no. 6, p. 2011-2017.

MACDONALD, JA., FOWLER, D., HARGREAVES, KJ., SKIBA, U., LEITH, ID. and MURRAY, MD., 1998. Methane emission rates from a northern wetland; response to temperature, water table and transport. Atmos. Environ., vol. 32, no. 19, p. 3219-3227.

MACINYRE, S., WANNINKHOF, R. and CHANTON, JP., 1995. Trace gas exchange across the air-water interface in freshwaters and coastal marine environments. In: Biogenic Trace Gases: Measuring Emissions from Soils and Waters, P.A. Mattson and R.C. Harris (eds), Blackwell, New York; p. 52-57.

MARINHO, CC., PALMA SILVA, C., ALBERTONI, EF., TRINDADE, CR. and ESTEVES, FA., 2009. Seasonal Dynamics of Methane in The Water Column of Two Subtropical Lakes Differing in Trophic Status. Braz. J. Biol., vol. 69 , no. 2, p. 281-287.

MOORE, TR. and DALVA, M., 1993. The influence of temperature and water table position on carbon dioxide and methane emissions from laboratory columns of peatland soils. J. Soil Sci., vol. 44, no. 4, p. 651-664.

NEUE, HU., WASSMANN, R., KLUDZE, HK., BUJUN, W and LANTIN, RS., 1997. Factors and processes controlling methane emissions from rice fields. Nutr. Cycl. Agroecosys., vol. 49, no. 1-3, p. 111-117.

PRAIRIE, YT., BIRD, DF. and COLE, JJ., 2002. The Summer Metabolic Balance in the Epilimnion of Southeastern Quebec Lakes. Limnol. Oceanogr., vol. 47, no. 1, p. 316321.

RICE, DD. and CLAYPOOL, GE., 1981. Generation, Accumulation, and Resource Potential of Biogenic Gas. AAPG Bull., vol. 65, p. 5-25.

RASK, H., SCHOENAU, J. and ANDERSON, D., 2002. Factors influencing methane flux from a boreal forest wetland in Saskatchewan, Canada. Soil Biol. Biochem., vol. 34, no. 4 , p. 435-443.

RIBEIRO FILHO, RA., PETRERE JUNIOR, M., BENASSI, SF. and PEREIRA, JMA., 2011. Itaipu Reservoir Limnology: Eutrophication Degree and the Horizontal Distribution of its Limnological Variables. Braz. J. Biol., vol. 71, no. 4, p. 889-902.

ROSA, LP. and SCHAEFFER, R., 1994a. Greenhouse Gas Emissions from Hydroelectric Reservoirs. Ambio, vol. 23, p. 164-165.

ROSA, LP., SANTOS, MA., MATVIENKO, B., SANTOS, EO. and SIKAR, E., 2004. Greenhouse Gas Emissions from Hydroelectric Reservoirs in Tropical Regions. Climatic Change, vol. 66, p. 9-21.

RUDD, JWM., HARRI,S R., KELLY, CA. and HECKY, RE., 1993. Are hydroelectric reservoirs significant sources of greenhouse gas? Ambio, vol. 22, p. 246-248.

SANTOS, MA., ROSA, LP., MATVIENKO, B., SIKAR, E. and SANTOS, EO., 2006. Gross greenhouse gas fluxes from hydro-power reservoir compared to thermo-power plants. Energ. Policy, vol. 34, p. 481-488.

SANTOS, MA., ROSA, LP., MATVIENKO, B., MADDOCK, JEL., PATHINEELAM, SR., SANTOS, EO. et al., 2011. Monitoramento de Emissões de Gases de Efeito Estufa em Reservatórios de Usinas Hidrelétricas. Relatório de Medições. Rio de Janeiro, 90p.

SIKAR, E., SANTOS, MA., MATVIENKO, B., SILVA, MB., ROCHA, CHED., SANTOS, EO., BENTES, AP. and ROSA, LP., 2005. Greenhouse gases and initial findings on the carbon circulation in two reservoirs and their watersheds. Verh. Internat. Verein Limnol., vol. 29, p. 573-576.

ST LOUIS, VL., KELLY, CA., DUCHEMIN, E., RUDD, JWM. and ROSENBERG, DM., 2000. Reservoir Surfaces as Sources of Greenhouse Gases to the Atmosphere: A Global Estimate. Bioscience, vol. 50, p. 766-775.

TREMBLAY, A. and SCHETAGNE, R., 2006. The Relationship between Water Quality and Greenhouse Gas Emissions in Reservoirs? Int. J. Hydropower Dams, vol. 13, p. 103-107.

UNESCO/IHA GREENHOUSE GAS, 2009. The UNESCO/IHA Measurement specification guidance for evaluating the GHG status of man-made freshwater reservoirs, Document Track, Edition 1, 57p.

TUNDISI, JG., MATSUMURA-TUNDISI, T. and ABE, DS., 2007. Climate Monitoring Before and During Limnological Studies: A Needed Integration. Braz. J. Biol., vol. 67, no. 4, p.795-796.

WANNIKHOF, R., 1992. Relationship between Wind Speed and Gas Exchange over the Ocean. J. Geophys. Res., vol. 97 , no. C5, p. 7373-7382. 
WEISSENBERGER, S., LUCOTTE, M., HOUEL, S., SOUMIS, N., DUCHEMIN, É. and CANUEL, R., 2010. Modeling the carbon dynamics of the La Grande hydroelectric complex in northern Quebec. Ecol. Model., vol. 221, p. 610-620.
WILKS, DS., 2006. Statistical Methods in the Atmospheric Sciences. 2nd ed. International Geophysics Series, vol. 91, Elsevier, Oxford, 627p.

YAVITT, JB., LANG, GE. and WIEDER, RK., 1987. Control of carbon mineralization to $\mathrm{CH}_{4}$ and $\mathrm{CO}_{2}$ in anaerobic Sphagnum-derived peat from Big Run Bog, West Virginia, Biogeochemistry, vol. 4, no. 2, p. 141-157. 